\title{
FAKTOR - FAKTOR YANG BERHUBUNGAN DENGAN INDEKS PRESTASI KUMULATIF MAHASISWA TINGKAT I DAN II DIII KEBIDANAN STIKes MERCUBAKTIJAYA PADANG TAHUN 2018
}

\author{
Dewi Susilawati, Eka Putri Prima Sari, Nur Fadjri Nilakesuma \\ STIKes MERCUBAKTIJAYA PADANG \\ Email : dewisusilawati39@gmail.com
}

\begin{abstract}
ABSTRAK
Indeks pembangunan dapat dilihat dari sumber daya manusia. Tiga faktor utama yang dapat menjadi penentu yaitu, pendidikan, kesehatan dan ekonomi. Faktor-faktor tersebut berkaitan dengan status gizi masyarakat. Karena, anak yang memperoleh makanan yang adekuat sejak dari kandungan (status gizi baik) akan tumbuh dan berkembang dengan optimal sesuai usianya dan mempunyai umur harapan hidup yang baik. Selain faktor gizi, keberhasilan belajar dan prestasi akademik dari mahasiswa juga dipengaruhi oleh anemia. Terdapat faktor lain yang mempengaruhi prestasi belajar, diantaranya adalah: perhatian orang tua, fasilitas belajar, waktu belajar, motivasi, intelegensi, minat, keterampilan guru mengajar dan lain sebagainya. Tujuan penelitian ini untuk mengetahui apakah ada hubungan status gizi, anemia, psikososial dengan indeks pretasi komulatif mahasiwa tingkat I dan II DIII Kebidanan STIKes Mercubaktijaya Padang Tahun 2018. Penelitian ini telah dilakukan pada tanggal 22 Februari s/d 30 April 2018 di STIKes Mercubaktijaya Padang, dengan jumlah sampel 39 mahasiswa prodi DIII Kebidanan dengan teknik Stratified Random Sampling. Penelitian ini dianalisis dengan uji chi-square. Hasil penelitian ini adalah terdapat hubungan antara status gizi, anemia dengan indeks prestasi kumulatif mahasiswa dimana nilai $\mathrm{p}$ value adalah 0,008 dan 0,026. Tidak terdapat hubungan antara Psikososial dengan indeks prestasi komulatif mahasiswa tingkat I dan II Prodi DIII Kebidanan STIKes Mercubaktijaya padang. Kesimpulan penelitian ini adalah terdapat hubungan antara status gizi, anemia dengan indeks prestasi komulatif dan tidak terdapat hubungan antara psikososial dengan indeks prestasi komulatif mahasiswa tingkat Idan II. Saran penelitian ini adalah diharapkan kepada mahasiswa untuk menjaga kualitas gizinya dan diperlukan kerjasama antara pihak pedidikan dengan orang tua dalam menjaga mengawasi kondisi kejiwaan mahasiswa.
\end{abstract}

\section{Kata Kunci : Status Gizi, Anemia, Psikososial, Mahasiswa, Indeks Prestasi Komulatif}

\begin{abstract}
Development index can be seen from human resources. The three main factors that can be determinants are education, health, and economy. These factors are related to the nutritional status of the community. Because children who get adequate food from the womb (well-nourished status) will grow and develop optimally according to their age and have a good life expectancy. In addition to nutritional factors, successful learning and academic achievement of students are also affected by anemia. There are other factors that influence learning achievement, including parents' attention, learning facilities, learning time, motivation, intelligence, interests, teacher teaching skills and so on. The purpose of this study was to determine whether there was an effect of nutritional status, anemia, psychosocial with the cumulative grade index of students grade I and II DIII Midwifery MERCUBAKTIJAYA Padang STIKES in 2018. This research was conducted on 22 February to 30 April 2018 at MERCUBAKTIJAYA STIKES Padang, with a sample of 39 students of Midwifery DIII study program with Stratified Random Sampling technique. This study was analyzed by chisquare test. The results of this study are that there is a relationship between nutritional status, anemia and student cumulative performance index where the $P$ value is 0.008 and 0.026. There is no relationship between Psychosocial and achievement indices for students at grade I and II of DIII Midwifery Program at STIKES MERCUBAKTIJAYA Padang. The conclusion of this study are that there is a relationship between nutritional status, anemia and student cumulative performance index and no relationship between Psychosocial and achievement indices for students at grade I and II. The suggestion of this research is that students are expected to maintain their nutritional quality and require cooperation between the education and parents in maintaining supervision over the mental condition of students.
\end{abstract}

Keywords : Nutritional Status, Anemia, Psychosocial, Students, Cumulative performance index 


\section{PENDAHULUAN}

Pembangunan kesehatan adalah salah satu bagian dari upaya pembangunan nasional, diarahkan guna tercapainya kesadaran, keinginan dan kemampuan untuk hidup bagi setiap penduduk agar dapat mewujudkan derjat kesehatan yang optimal.Upaya pembangunan kesehatan yang optimal harus dapat menunjang pembanguan sumber daya manusia yang maju, mandiri serta sejahtera lahir dan batin (Khairunnisa, 2013).

Mahasiswa secara universal diapresiasikan sebagai penerus bangsa yang sudah matang di bidang akademik. Dalam proses belajar pun tingkat penalaran sudah cukup baik dan meluas. Arum (2010) mengungkapkan kecerdasan emosional sangat berhubungan dengan prestasi. Dengan kecerdasan emosional yang tinggi, misalnya ketika seorang anak berada dalam keadaan flow maka mereka akan lebih mudah untuk menerima pelajaran yang diberikan oleh guru dan pada akhirnya mampu mencapai prestasi belajar memuaskan. Keadaan flow adalah dimana kondisi seseorang hanyut dalam sebuah aktivitas seakan tidak ada yang bisa mengganggu perhatiannya. Pengalaman tersebut sekaligus terasa menyenangkan untuk tetap dilakukan, sehingga seseorang akan tetap melakukannya walaupun tantangannya besar. Pada setiap proses belajar yang dilakukan secara kontinyu dan didukung dengan kecerdasan emosional yang cukup baik, prestasi akademik dapat ditingkatkan (Arum,
2010).

Dalam buku peraturan akademik STIKes MERCUBAKTIJAYA Padang 2016-2017 menyebutkan bahwa hasil belajar mahasiswa dinyatakan dalam bentuk Indeks Prestasi (IP) terdiri atas: Lembar Hasil Studi (LHS) yang menunjukkan IP pada semester tertentu,dan Indeks Prestasi Kumulatif (IPK) yang menunjukkan IP pada akhir studi (STIKes MERCUBAKTIJAYA, 2016).

Indeks pembangunan dapat dilihat dari sumber daya manusia.Tiga faktor utama yang dapat menjadi penentu yaitu, pendidikan, kesehatan dan ekonomi. Faktor-faktor tersebut berkaitan dengan status gizi masyarakat. Karena, anak yang memperoleh makanan yang adekuat sejak dari kandungan (status gizi baik) akan tumbuh dan berkembang dengan optimal sesuai usianya dan mempunyai umur harapan hidup yang baik. Keadaan status gizi dan indeks prestasi merupakan gambaran apa yang dikonsumsi seseorang dapat berupa gizi kurang maupun gizi lebih. Zat-zat berupa protein, karbohidrat maupun kandungan gizi lainnya khususnya zat besi, dalam metabolisme tubuh berperan dalam proses dalam berpikir atau penalaran dan kemampuan konsentrasi sangat berhubungan dengan efisiensi belajar. Dengan keadaan gizi yang baik diharapkan berdampak pada prestasi belajar yang baik pula (Hayatus, Herman, Sastri, 2014 ). 
Berdasarkan penelitian Ghosh, dkk tahun 2013 menyatakan siswa yang melakukan diet memiliki nilai lebih rendah dibandingkan dengan siswa yang tidak melakukan diet. Prayogi juga menyatakan dalam penelitiannya tahun 2016, dimana terdapat hubungan bermakna antara status gizi dengan indek pretasi komulatif mahasiswa di fakultas kedokteran unversitas Lampung.

Selain faktor gizi, keberhasilan belajar dan prestasi akademik dari mahasiswa juga dipengaruhi oleh anemia. Anemia adalah masalah kesehatan dunia saat ini, salah satunya anemia karena defisiensi zat besi (Sudoyo dkk, 2009). Anemia di Indonesia masih merupakan salah satu masalah gizi yang utama di samping kekurangan kalori protein (KKP), defisiensi vitamin dan yodium.Sekitar

2 milyar penduduk, atau lebih dari 30\% penduduk dunia menderita anemia. Di negara berkembang prevalensi anemia cukup tinggi.Sekitar 370 juta jiwa wanita di negara berkembang mengalami anemia (Widyastuti

\& Hardiyanti, 2008). Berdasarkan Riset Kesehatan Dasar Indonesia anemia gizi besi pada anak balita sebesar $28,1 \%$, anak umur 5-12 tahun $20 \%$, ibu hamil $37,1 \%$, remaja putri umur 13-18 tahun dan wanita usia subur 15-49 tahun masing-masing sebesar $22,7 \%$ (Riskesda, 2013).

Penelitian yang dilakukan oleh Soleimani dan abbaszadeh tahun 2011, di Iran menyatakan nilai prestasi dengan anemia jauh lebih rendah dibandingkan siswa yang sehat. Hasil penelitian ini juga sama dengan penelitian yang dilakukan oleh Astiandani dan Rokhanawati tahun 2015, bahwa ada hubungan antara kejadian anemia dengan prestasi belajar matematika pada remaja putri kelas 11 di SMAN 1 Sedayu Tahun 2015.

Anemia dapat mengakibatkan berkurangnya daya fikir dan kosentrasi seseorang sehingga dapat menurunnya prestasi belajar pada anak, ini disebabkan karena sulitanya anak untuk berkosentarasi. Menurut Arisman (2009) dampak negatif lainnya yang bisa ditimbulkan anemia adalah kurangnya daya tahan tubuh sehingga mudah di serang penyakit, serta menurunya kemampuan kinerja intelektual seseorang.

Keberhasilan belajar dan prestasi akademik dari mahasiswa juga dipengaruhi oleh dua faktor, yaitu faktor internal dan faktor eksternal. Faktor internal meliputi, kecerdasan, minat, bakat, orang tua, dukungan, kesehatan fisik dan cara belajar seseorang. Faktor eksternal meliputi, keluarga, lingkungan, guru, masyarakat, sekolah serta peralatan atau sarana belajar. Berdasarkan hal itu, diketahui bahwa terdapat faktor yang mempengaruhi prestasi belajar, diantaranya adalah: perhatian orang tua, fasilitas belajar, waktu belajar, motivasi, intelegensi, minat, keterampilan guru mengajar dan lain sebagainya (Bangun, 
2008).

Kecemasan adalah hal yang normal di dalam kehidupan karena kecemasan sangat dibutuhkan sebagai pertanda akan bahaya yang mengancam. Namun ketika kecemasan terjadi terus-menerus, tidak rasional dan intensitasnya meningkat, maka kecemasan dapat mengganggu aktivitas sehari-hari dan disebut sebagai gangguan kecemasan (ADAA, 2010). Sedangkan depresi dapat menyebabkan manifestasi psikomotor seperti keadaan semangat, gairah, aktivitas, produktivitas kerja yang menurun, konsentrasi dan daya pikir yang melambat. Manifestasi psikomotor itu sendiri dapat membawa pengaruh terhadap prestasi belajar jika penderita sedang aktif dalam proses belajar mengajar (Setyonegoro, 2000).

Kecemasan juga dapat didefinisikan sebagai kondisi emosional yang tidak menyenangkan, ditandai perasaan-perasaan yang ada dari diri sendiri seperti kondisi tegang, takut, khawatir dan juga ditandai dengan aktifnya sistem syaraf pusat. Sehingga kecemasan termasuk ke dalam status psikososial yang berpengaruh terhadap indeks prestasi kumulatif (IPK) mahasiswa (Mu'arifah, 2005).

Berdasarkan penelitian yang dilakukan oleh Djumadi (2015) Setelah dilakukan analisis data secara statistik didapatkan nilai $\mathrm{p}=0,000$ yang artinya $\mathrm{p}<0,001$. Dengan demikian dapat disimpulkan bahwa secara statistik terdapat hubungan yang sangat bermakna antara tingkat kecemasan dan prestasi akademik mahasiswa Fakultas Psikologi Universitas Muhammadiyah Surakarta.

Di dalam suatu proses pendidikan, seorang mahasiswa dikatakan berhasil apabila dapat menyelesaikan pembelajaran dengan hasil yang baik. Prestasi belajar yang baik merupakan hal yang paling didambakan oleh setiap mahasiswa yang sedang belajar, prestasi belajar dapat dijadikan indikator keberhasilan seseorang dalam kegiatan belajar (Arum, 2010). Data yang didapatkan dari bagian akademik STIKes MERCUBAKTIJAYA Padang Prodi DIII Kebidanan untuk distribusi IPK mahasiswa tingkat 1 dan 2 yaitu sebanyak $31,44 \%$ mahasiswa mendapatkan IPK kurang dari $2(<2,00)$. Dengan data yang didapatkan tersebut berarti masih ada mahasiswa yang mendapatkan IPK kurang dan perlu diteliti faktor penyebabnya. (STIKes MECUBAKTI JAYA Padang, 2016).

Berdasarkan permasalah diatas maka peneliti tertarik untuk meneliti "Faktor-Faktor yang Berhubungan Indek Prestasi Komulatif Mahasiswa Tingakt I dan II DIII Ke bidanan STIKes MERCUBAKTIJAYA Padang Tahun 2018".

\section{METODOLOGI}

Jenis penelitian ini adalah deskriptif analitik dengan rancangan Cross Sectional. Variebel terikat adalah indeks prestasi komulatif (IPK), 
variabel bebas adalah satus gizi, anemia, dan psiskososial. Pengumpulan data telah dilakukan pada tanggal 28 Februari - 30 April 2018 di STIKes MERCUBAKTIJAYA Padang. Sampel penelitian ini adalah sebagaian dari jumlah mahasiswa tingkat I dan II mahasiswa DIII Kebidanan STIKes MERCUBAKTIJAYA Padang dengan jumlah sampel penelitian ini adalah 39 mahasiswa dimana tekni pengambilan sampelnya Stratified Random Sampling. Penelitian ini dianalisis dengan uji chi-square.

\section{HASIL PENELITIAN DAN}

\section{PEMBAHASAN}

\section{Analisa Univariat}

\section{Distribusi Frekuensi Indeks Prestasi Kumulatif Mahasiswa tingkat I dan II Prodi DIII Kebidanan STIKes MER CUBAKTIJAYA Padang}

Tabel 1 Distribusi Frekuensi Indeks Prestasi Kumulatif Mahasiswa tingkat I dan II Prodi DIII Kebidanan STIKes MERCUBAKTIJAYA Padang

\begin{tabular}{cccc}
\hline No & IPK & Jumlah & \% \\
\hline 1. & Memuaskan & 10 & 25.6 \\
2. & Sangat Memuaskan & 18 & 46.2 \\
3. & Dengan Pujian & 11 & 28.2 \\
& Jumlah & 39 & 100 \\
\hline
\end{tabular}

Berdasarkan tabel 1 didapatkan bahwa dari 39 orang responden, sebanyak 10 orang (25.6\%) dengan predikat IPK memuaskan, 18 orang $(46.2 \%)$ dengan predikat IPK sangat memuaskan, dan 11 orang $(28.2 \%)$ dengan predikat IPK dengan pujian.

Dari hasil penelitian diatas dapat disimpulan bahwa IPK yang dicapai oleh oleh mahasiswatingkat I dan II Prodi DIII kebidanan STIKes MERCUBAKTIAJAYA padang adalah sangat bagus karenan dapat dilihat hamipr seperoh mahasiswa memiliki IPK lebih dari > 3 ( memuasakan) dan bahakan lebih dari seperempat memiliki IPK > 3.5 (dengan Pujian).

\section{Distribusi Frekuensi Status Gizi} Maha siswa tingkat I dan II Prodi DIII Kebid anan STIKes

\section{MERCUBAKTIJAYA Pa dang.}

Tabel 2

Distribusi Frekuensi Status Gizi Mahasiswa tingkat I dan II Prodi DIII Kebidanan STIKes MERCUBAKTIJAYA Padang

\begin{tabular}{cccc}
\hline+ & Status GIzi & Jumlah & \% \\
\hline 1. & Kurus & 8 & 20.5 \\
2. & Normal & 22 & 56.4 \\
3. & Gemuk & 9 & 23.1 \\
& Jumlah & 39 & 100 \\
\hline
\end{tabular}

Berdasarkan tabel 2 didapatkan bahwa dari 39 orang responden, sebanyak 8 orang (20.5\%) dengan status gizi kurus, 22 orang (56.4\%) dengan status gizi normal, dan 9 orang $(23.1 \%)$ dengan status gizi gemuk.

\section{Distribusi Frekuensi Anemia} Mahasiswa tingkat I dan II 


\section{Prodi DIII Kebidanan \\ STIKes MERCUBAKTIJAYA \\ Padang}

Tabel 3 Distribusi Frekuensi Anemia Mahasiswa tingkat I dan II Prodi DIII Kebidanan STIKes

MERCUBAKTIJAYA Padang

\begin{tabular}{cccc} 
No & Anemia & Jumlah & \% \\
\hline 1. & Tidak Anemia & 28 & 71.8 \\
2. & Anemia & 11 & 28.2 \\
& Jumlah & 39 & 100 \\
\hline
\end{tabular}

Berdasarkan tabel 3 didapatkan bahwa dari 39 orang responden, sebanyak 28 orang $(71.8 \%)$ tidak anemia, dan 11 orang $(28.2 \%)$ mengalami anemia.

\section{Distribusi Frekuensi Psikososial Mahasiswa tingkat I dan II Prodi DIII Kebidanan MERCUBAKTIJAYA}

\section{Padang}

Tabel 4 Distribusi Frekuensi Psikososial Mahasiswa tingkat I dan II Prodi DIII Kebidanan STIKes MERCUBAKTIJAYA Padang

\begin{tabular}{rccc}
\hline No & Psikososial & Jumlah & \% \\
\hline 1. & Tidak ada kecemasan & 7 & 17.9 \\
2. & Cemas Ringan & 20 & 51.3 \\
3. & Cemas Sedang & 12 & 30.8 \\
4. & Cemas Berat & 0 & 0 \\
& Jumlah & 39 & 100 \\
\hline
\end{tabular}

Berdasarkan tabel 4 didapatkan bahwa dari 39 orang responden, sebanyak 7 orang (17.9\%) dengan psikososial tidak ada kecemasan, 20 orang $(51.3 \%)$ dengan psikososial cemas ringan, 12 orang (30.8\%) dengan psikososisal cemas sedang dan 0 orang $(0 \%)$ dengan psikososial cemas berat.

\section{Analisa Bivariat}

\section{Hubungan Status Gizi dengan Indeks}

Prestasi Kumulatif Mahasiswa tingkat I dan II Prodi DIII Kebidanan STIKes MERCUBAKTIJAYA Padang

Tabel 5. Hubungan Status Gizi dengan Indeks Prestasi Kumulatif Mahasiswa tingkat I dan II Prodi DIII Kebidanan STIKes MERCUBAKTIJAYA Padang

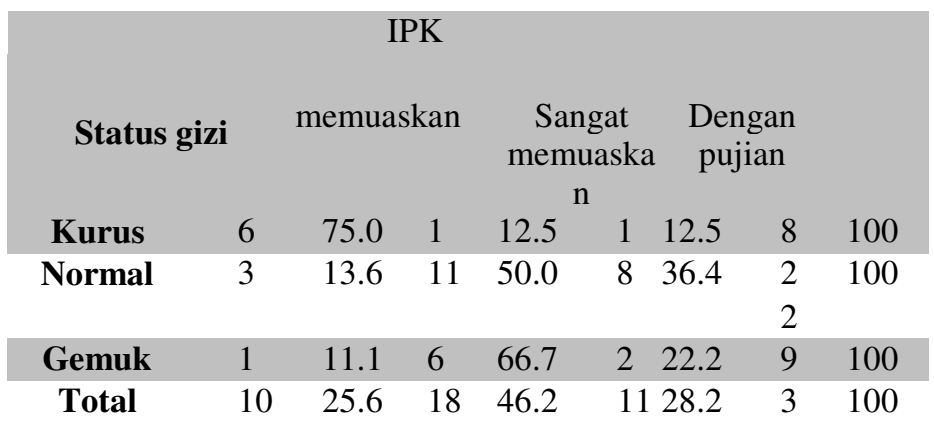

Berdasarkan tabel 5, didapatkan data dari 22 orang responden dengan status gizi normal, 3 orang (13.6\%) mendapatkan IPK memuaskan, 11 orang (50\%) mendapatkan IPK sangat memuaskan dan 8 orang (36.4\%) mendapatkan IPK dengan pujian. Hasil uji statistic dengan uji Chi - Square didapatkan nilai $\rho=0,008$, yang artinya ada hubungan antara status gizi dengan indeks kumulatif mahasiswa.

Hasil penelitian ini sama dengan penelitian yang dilakukan oleh Khairunnisa tahun 2011, dimana terdapat hubungan antara status gii dengan IPK (p value 0,000 dan OR 9,778). Hasil penelitian ini menunjukkan besarnya pengaruh status gizi 
dengan IPK.

Hasil pennelitian ini juga didukung oleh teori anak yang memperoleh makanan yang adekuat sejak dari kandungan (status gizi baik) akan tumbuh dan berkembang dengan optimal sesuai usianya dan mempunyai umur harapan hidup yang baik. Dengan keadaan gizi yang baik diharapkan berdampak pada prestasi belajar yang baik pula (Hayatus, Herman, Sastri, 2014 ).

Berdasarkan penelitian Ghosh, dkk tahun 2015

Menyatakan siswa yang melakukan diet memiliki nilai lebih rendah dibandingkan dengan siswa yang tidak melakukan diet.

Prayogi juga menyatakan dalam penelitiannya tahun 2016, dimana terdapat hubungan bermakna antara status gizi dengan indek pretasi komulatif mahasiswa di fakultas kedokteran unversitas Lampung.

Pada penelitian ini peneliti menilai status gizi mahasiswa dengan mengumpulkan data menggunakan menggunakan pengukuran langsung pada mahasiswa dengan melakukan pengukuran IMT (indeks masa tubuh) yaitu pengukran tinggi badan dan berat badan.

Kenyataan yang didapatkan ternayata status gizi mahasiswa prodi DIII Kebidanan STIKes MERCUBAKTIJAYA Padang dikategorian normal. Dalam hal ini peneliti berpendapat bahwa status gizi mahasiswa yang normal mempengaruhi IPK.
2. Hubungan Anemia dengan Indeks Prestasi Kumulatif Mahasiswa tingkat I dan II Prodi DIII Kebidanan STIKes

\section{MERCUBAKTIJAYA Padang}

Tabel 6. Hubungan Anemia dengan Indeks Prestasi Kumulatif Mahasiswa tingkat I dan II Prodi DIII Kebidanan STIKes MERCUBAKTIJAYA Padang

\begin{tabular}{|c|c|c|c|c|c|}
\hline \multirow[t]{3}{*}{ Anemis } & \multicolumn{5}{|l|}{ IPK } \\
\hline & $\begin{array}{c}\text { Memuask } \\
\text { an }\end{array}$ & $\begin{array}{c}\text { Sangat } \\
\text { memuask } \\
\text { an }\end{array}$ & $\begin{array}{c}\text { Dengan } \\
\text { x pujian }\end{array}$ & & otal \\
\hline & $\%$ & f $\%$ & f $\%$ & $\mathrm{~F}$ & $\%$ \\
\hline Tidak Anemia & 14.3 & 1450 & 1035.7 & 28 & 100 \\
\hline Anemia & 54.5 & $4 \quad 36.4$ & 19.1 & 11 & 100 \\
\hline Total & 1025.6 & 1846.2 & 1128.2 & 39 & 100 \\
\hline
\end{tabular}

Berdasarkan tabel 6, didapatkan data dari 11 orang responden dengan anemia, 6 orang (54.5\%) mendapatkan IPK memuaskan, 4 orang (36.4\%) mendapatkan IPK sangat memuaskan dan 1orang (9.1\%) mendapatkan IPK dengan pujian. Hasil uji statistic dengan uji Chi Square didapatkan nilai $\rho=0,026$, yang artinya ada hubungan antara anemia dengan indeks kumulatif mahasiswa.

Hasil penelitian ini sama dengan penelitian yang dilakukan oleh Prananingrum dan Asriari tahun 2015, diaman terdapat hubungan kadar hemoglobin dengan IPK mahasiswa $(0,043)$.

Penelitian yang dilakukan oleh Soleimani dan abbaszadeh tahun 2011, di Iran juga menyatakan bahwa nilai prestasi dengan anemia jauh lebih rendah dibandingkan siswa yang sehat. Hasil 
penelitian ini juga sama dengan penelitian yang dilakukan oleh Astiandani dan Rokhanawati tahun 2015, bahwa ada hubungan antara kejadian anemia dengan prestasi belajar matematika pada remaja putri kelas 11 di SMAN 1 Sedayu Tahun 2015.

Anemia dapat mengakibatkan berkurangnya daya fikir dan kosentrasi seseorang sehingga dapat menurunnya prestasi belajar pada anak, ini disebabkan karena sulitanya anak untuk berkosentarasi.Menurut Arisman (2009) dampak negatif lainnya yang bisa ditimbulkan anemia adalah kurangnya daya tahan tubuh sehingga mudah di serang penyakit, serta menurunya kemampuan kinerja intelektual seseorang.

Pada penelitian ini peneliti menilai kejadian anemia pada mahasiswa dengan mengumpulkan data menggunakan menggunakan pengukuran langsung pada mahasiswa dengan melakukan pengukuran kadar hemoglobin mahasiswa.

Kenyataan yang didapatkan ternyataan kejadian anemia pada mahasiswa prodi DIII Kebidanan STIKes MERCUBAKTIJAYA Padang dikategorian tidak anemia. Dalam hal ini peneliti berpendapat bahwa mahasiswa yang tidak melangalami anemia lebih tinggi IPK dibandingkan yang anemia, walapun ada mahasiswa yang mengalami anemia dengan IPK yang tinggi, karena faktor rendanya IPK tidak hanya di pengaruhi oleh anemia tetapi masih banyak faktor yang mempengaruhnya.
3. Hubungan Psikososial dengan Indeks Prestasi Kumulatif Mahasiswa tingkat I dan II

Prodi DIII Kebidanan
MERCUBAKTIJAYA Padang

Tabel 7. Hubungan Psikososial dengan Indeks

Prestasi Kumulatif Mahasiswa tingkat I dan II Prodi DIII Kebidanan STIKes MERCUBAKTIJAYA Padang

\begin{tabular}{|c|c|c|c|c|c|c|c|c|}
\hline \multirow{3}{*}{ Psikososie } & \multicolumn{6}{|c|}{ IPK } & \multirow[b]{3}{*}{$\mathrm{F}$} & \multirow[b]{3}{*}{$\%$} \\
\hline & \multicolumn{2}{|c|}{$\begin{array}{c}\text { Memuask } \\
\text { an }\end{array}$} & \multicolumn{2}{|c|}{$\begin{array}{c}\text { Sangat } \\
\text { Memuaska } \\
\mathrm{n}\end{array}$} & \multicolumn{2}{|c|}{$\begin{array}{c}\text { Dengan } \\
\text { Pujian }\end{array}$} & & \\
\hline & f & $\%$ & $\mathrm{f}$ & $\%$ & $\mathrm{f}$ & $\%$ & & \\
\hline $\begin{array}{l}\text { Tidak Ada } \\
\text { kecemasan }\end{array}$ & 1 & 14.2 & 2 & 28.6 & 4 & 57.2 & 7 & 100 \\
\hline $\begin{array}{l}\text { Cemas } \\
\text { Ringan }\end{array}$ & 5 & 25 & 9 & 45 & 6 & 30 & 20 & 100 \\
\hline $\begin{array}{l}\text { Cemas } \\
\text { Sedang }\end{array}$ & 4 & 33.3 & 7 & 58.4 & 1 & 8.3 & 12 & 100 \\
\hline Total & 10 & 25.6 & 18 & 46.2 & 11 & 28.2 & 39 & 100 \\
\hline
\end{tabular}

Berdasarkan tabel 7, didapatkan data dari 12 orang responden dengan kecemasan sedang, 4 orang $(33.3 \%)$ mendapatkan IPK memuaskan,

7 orang (58.4\%) mendapatkan IPK sangat memuaskan dan 1 orang $(8.3 \%)$ mendapatkan IPK dengan pujian. Hasil uji statistic dengan uji Chi - Square didapatkan nilai $\rho=0,293$, yang artinya tidak ada hubungan antara psikososial dengan indeks kumulatif mahasiswa.

Hasil penelitian ini berbeda dengan penelitian yang dilakukan oleh Djumadi Akbar tahun 2015, dimana hasil penelitian ini didapatkan hubungan antara psikososial dengan indeks prestasi belajar mahasiswa. Terdapat perbedaan hasil mungkin disebabkan karena tingkat kecemasan 
mahasiswa yang diukur dengan koesioner TMAS (Taylor Manifest Anxiety Scule), sementara penelitian ini tingkat kecemasan mahasiswa yang diukur dengan koesioner Hamilton Rating Scale for Anxiety (HRS-A). Kecemasan juga dapat didefinisikan sebagai kondisi emosional yang tidak menyenangkan, ditandai perasaan-perasaan yang ada dari diri sendiri seperti kondisi tegang, takut, khawatir dan juga ditandai dengan aktifnya sistem syaraf pusat. Sehingga kecemasan termasuk ke dalam status psikososial yang berpengaruh terhadap indeks prestasi kumulatif (IPK) mahasiswa (Mu'arifah, 2005).

\section{KESIMPULAN}

Hampir separoh mahasiswa tingkat I dan II STIKes MERCUBAKTIJAYA memiliki IPK yang di kategorikan sangat memuaskan yaitu $46,2 \%$, lebih dari separoh mahasiswa tingkat I dan II STIKes MERCUBAKTIJAYA memiliki status gizi normal yaitu 56,4 \%, lebih dari separoh mahasiswa tingkat I dan II STIKes MERCUBAKTIJAYA tidak mengalami anemia yaitu $71,8 \%$, lebih dari separoh mahasiswa tingkat I dan II STIKes MERCUBAKTIJAYA mengalami cemas ringan yaitu $51,3 \%$.

Terdapat hubungan status gizi dengan IPK mahasiswa tingkat I dan II STIKes MERCUBAKTIJAYA dimana nilai $\mathrm{p}$ value yaitu 0,008 , terdapat hubungan anemia dengan mahasiswa tingkat I dan II STIKes MERCUBAKTIJAYA dimana nilai $\mathrm{p}$ value yaitu 0,026, tidak ada hubungan psikologi dengan mahasiswa tingkat I dan II STIKes MERCUBAKTIJAYA dimana nilai $\mathrm{p}$ value yaitu 0,293

\section{SARAN}

Diharapkan kepada mahasiswa untuk menjaga kwalitas gizi yang sudah dinyatakan normal, dan bagi mahasiswa yang kwalitas gizinya kurus dan gemuk maka perlu untuk memperbaikinya sehingga tidak ditemukan lagi IPK yang rendah. Di perlukan adanya kerjasama aktif pihak pendidikan dengan orang tua dalam mengawasi kondisi kejiwaan mahasiswa serta hasil penelitian ini dapat digunakan sebagai masukan memberikan bimbingan dan menyediakan tempat konsultasi bagi mahasiswa. Diharapkan dapat menjadi masukan dan pembelajaran bagi mahasiswa serta bagaimana mengatasi agar tingkat kecemasan yang dialami mahasiswa tidak mempengaruhi prestasi akademik.

\section{KEPUSTAKAAN}

ADAA. (2010). Anxiety and Depression Association Of America.

Arum P. (2010).Pengaruh kecerdasan emosi terhadap prestasi siswa mata pelajaran seni budaya Sekolah Menengah Pertama.Jurusan Sendratasik, Fakultas Bahasa dan Seni. Semarang: Universitas Negeri Semarang.

Arisman. (2009).Gizi dalam Daur Kehidupan.

Jakarta : EGC. 193-195

Astiandani Ari dan Rokhanawati Dewi. (2015). 
Hubungan Kejadian Anemia dengan Prestasi Belajar Matematika Pada Remaja Putri Kelas 11 di SMA 1 Sedayu. Skripsi Thesis. STIKes Aisyiyah Yogyakarta

Bangun D. (2008). Hubungan Persepsi Siswa Tentang Perhatian Orang Tua, Kelengkapan Fasilitas Belajar dan Penggunaan Waktu Belajar di Rumah Dengan Prestasi Belajar Ekonomi. 5(April). 74-94

Djumadi Akbar. (2015). Hubungan Antara Tingkat Kecemasan Dengan Prestasi Akademik Mahasiswa di Fakultas Psikologi Universitas Muhammadiyah Surakarta. Surakarta: Universitas Muhammadiyah Surakarta.

Ghosh, N. Rakshit,S. Bhattacharya,M. (2013). Academic Performance and Nutritional Status - A Case Study on College Students in North Tripura. IOSR Journal of Research \& Method in Education (IOSR-JRME) e-ISSN: 2320-7388,p-ISSN: 2320-737X

Volume 1, Issue 4 (May. -Jun. 2013), PP 57-68 www.iosrjournals.org

Hayatus R, Herman RB, Sastri S. (2014).

Artikel Penelitian Hubungan Status Gizi

dengan Prestasi Belajar Siswa Sekolah Dasar Negeri 01 Guguk Malintang Kota Padangpanjang. 3(3): 460-465.

Khairunnisa A. (2013). Hubungan Status Gizi Dengan Indeks Prestasi Kumulatif Mahsiswa akademi Kebidanan.Journal of Chemical Information and Modeling. 53(9): 1-6.

Mu'arifah A. (2005). Hubungan Kecemasan dan Agresivitas. 2(2): 102-111.

Prayogi Sitiawan. (2016). Hubungan Status Gizi, Status Psikososial Terhadap Indeks Pretasi Komulatif (IPK) Mahasiswa Tingkat 2 dan 3 Fakultas Kedoteran Universitas Lampung. Skripsi

Prananingrum Ratih dan Asriari Reza Dea. (2015). Analisis Kadar Hemoglobin
Dengan Indeks Prestasi Kumulatif (IPK) Mahasiswi. University Research Colloqium. STIKes PKU Muhammadiyah Surakarta.

Rikesdas. 2013. Riset Kesehatan Dasar Tahun 2013

STIKes MERCUBAKTIJAYA. (2016). Panduan Akademik STIKes MERCUBAKTIJAYA. Padang

Setyonegoro RK, Iskandar Y. (2000). Depresi Suatu Problema Diagnosa dan Terapi pada Praktek Umum. Jakarta: Yayasan Darma Graha. 9-16.

Setyonegoro RK, Iskandar Y. (2000). Depresi Suatu Problema Diagnosa dan Terapi pada Praktek Umum. Jakarta: Yayasan Darma Graha. 9-16.

Sudoyo A W, Setyohadi B, Alwi I dkk. (2009.) Buku Ajar Ilmu Penyakit Dalam. Jilid III Edisi V. Jakarta: Interna Publishing Pusat Penerbitan Ilmu Penyakit Dalam.

Soleimani dan abbaszadeh. (2011) Relationship between anaemia, caused from the iron deficiency, and academic achievement among third grade high school female students. International Conference on Education and Educational Psychology (ICEEPSY). ELSEVIER 1877 1884

https://www.researchgate.net 